\title{
POLSKIE BADANIA NAD POSTACIA METROPOLITY ANDRZEJA SZEPTYCKIEGO
}

\section{Magdalena NOWAK}

\section{ABSTRACT}

\section{POLISH STUDIES ON METROPOLITAN ANDREI SHEPTYTS'KYI}

Andrei Sheptyts'kyi has been the object of interests of scholars in Poland of both Polish and Ukrainian origin. Polish studies on metropolitan Andrei Sheptyts'kyi have begun form publications of historical sources. They have been prepared by scholars who have performed first analysis of facts connected with his life and activity. The most important Polish researches on metropolitan started after 1989/1990. Since then a number of monographies concentrating on various aspects of his activity have been prepared. However, a majority of Polish publications on the topic have been single papers each dealing with a particular problem of Sheptyts'kyi's life and thought. Those have rarely been continued by their authors. Further research on metropolitan requires more effective cooperation between Polish and Ukrainian historians in order to propose the most complementary picture of Sheptyts'kyi's personality.

\section{KEYWORDS:}


Przełom XIX i XX wieku stanowił bardzo ważny moment w kształtowaniu się tożsamości narodowej na obszarze Europy Środkowej i Wschodniej. Zachodzące w tym czasie dynamiczne przemiany modernizacyjne obejmowały także proces identyfikacji narodowej Polaków i Ukraińców, który stał się jedną z przyczyn narastania konfliktu polsko-ukraińskiego w pierwszej połowie XX w. Wzajemne powiązanie wielu zjawisk (społecznych, politycznych, gospodarczych i kulturowych) oraz waga tamtych wydarzeń dla współczesnych relacji polsko-ukraińskich sprawiły, iż przełom XIX i XX w. był od lat przedmiotem żywego zainteresowania polskich i ukraińskich badaczy.

Postacią, w której życiu i działalności zdawały się ogniskować wspomniane wyżej zjawiska, był metropolita Andrzej Szeptycki. Z racji sprawowanej funkcji i aktywności na wszystkich najważniejszych polach życia społeczności ukraińskiej znalazł się on w samym centrum ówczesnych wydarzeń. Jego rodzina oraz dzieciństwo wiązało go bardziej z kulturą i środowiskiem polskim, natomiast część tradycji rodowej Szeptyckich i jego własne indywidualne wybory prowadziły do świadomego opowiedzenia się po stronie ukraińskich aspiracji narodowych. $Z$ tego powodu ukraińscy i polscy naukowcy różnych specjalności od lat analizowali jego postać, stawiając pytania z różnych perspektyw badawczych. Niniejsza wypowiedź stanowi jedynie próbę charakterystyki najważniejszych dokonań polskich uczonych w tym zakresie, ze szczególnym uwzględnieniem opracowań historycznych. Należy podkreślić, że myśl i działalność Szeptyckiego była analizowana w Polsce przede wszystkim, ale nie wyłącznie, przez historyków, teologów i filologów, przy czym część badaczy często podejmowała pracę przekraczającą granice jednej dyscypliny. Należy podkreślić, że część z nich wywodziła się z ukraińskiej wspólnoty narodowej żyjącej w granicach państwa polskiego. Warto też zaznaczyć szeroki zasięg tematyczny i chronologiczny podejmowanych zagadnień, zrozumiały jeśli się weźmie pod uwagę lata życia metropolity oraz rozmiar jego aktywności i kontekstów, w których się ona ujawniała, a także bogactwo bazy źródłowej.

Prace polskiego środowiska naukowego nad życiem i działalnością metropolity Szeptyckiego zainicjowały wydawnictwa źródłowe. Wkrótce po śmierci Zofii Szeptyckiej, Stanisław Tarnowski opublikował w latach 1906 i 1907 dwa tomy jej Pism, zawierające fragmenty literackie i wspomnienie o kuzynce Wandzie ze Skrzyńskich Ostrowskiej'. We wstępie do tej pracy Tarnowski zawarł charakterystykę postaci matki metropolity, która będzie następnie przywoływana przez uczonych badających środowisko rodzinne Szeptyckich. Inne publikacje źródłowe wiązały się początkowo przede wszystkim z osobą dziadka Andrzeja Szeptyckiego, Aleksandra Fredry i jego

Pisma Zofii z Fredrów Szeptyckiej, t. 1, Kraków 1906; t. 2, Kraków 1907. 
otoczeniem ${ }^{2}$. Jeszcze przed II wojną światową ukazały się przygotowane przez krytyka literackiego i teatralnego Adama Grzymałę-Siedleckiego wspomnienia Marii z Fredrów Szembekowej pt. Niegdyś... Wspomnienia moje o Aleksandrze Fredrze $e^{3}$. Po wojnie zaś pracę nad krytycznym wydaniem dział komediopisarza podjął Stanisław Pigoń. $\mathrm{Z}$ przygotowanej przez niego serii wydawniczej Pisma wszystkie [A. Fredry]. Wydanie krytyczne na szczególną uwagę, w kontekście postaci metropolity, zasługuje tom XIV: Korespondencja ${ }^{4}$. Szerzej zakrojoną pracę nad spuścizną związaną pośrednio z Szeptyckim podjął literaturoznawca Bogdan Zakrzewski. W 1967 r. wydał on Wspomnienia z lat ubieglych ${ }^{5}$, rękopis Zofii z Fredrów Szeptyckiej mający charakter pamiętnika rodzinnego. Kontynuując swoją pracę, w 1974 r. Zakrzewski opublikował tom źródłowy pt. Fredro ifredrusie ${ }^{6}$, który udostępniał czytelnikom część bogatej korespondencji oraz spuścizny rękopiśmiennej rodziny „polskiego Moliera”. W 1993 r. ukazała się kolejna książka w opracowaniu historyka literatury, tym razem już bezpośrednio związana z postacią Szeptyckiego, Młodość i powotanie ojca Romana Andrzeja Szeptyckiego zakonu św. Bazylego Wielkiego ${ }^{7}$, pióra jego matki Zofii Szeptyckiej. Wszystkie te publikacje stanowią do dziś ważny materiał przybliżający rodzinny kontekst, lata młodości, edukacji świeckiej oraz zakonnej przyszłego metropolity. Należy podkreślić też wpływ, prowadzonych przez Bogdana Zakrzewskiego, prac związanych z przygotowaniem tekstów źródłowych, które stały się integralną częścią publikacji. Znalazły one swoją kontynuację w opracowaniach powstających na podstawie materiałów źródłowych.

Wzrost liczby publikacji źródłowych dotyczących bezpośrednio metropolity Szeptyckiego daje się zauważyć w Polsce od przełomu lat 80. i 90. XX wieku, a zwłaszcza w latach po 1989 r. Już w 1985 r. historyk Stanisław Stępień opublikował i opatrzył wstępem Nieznany list Metropolity Andrzeja Szeptyckiego do Administratora Apostolskiego Łemkowszczyzny Wasyla Maściucha ${ }^{8}$. Wkrótce też, w tomie 1 (1990), wychodzącej pod jego redakcją serii Polska-Ukraina 1000 lat sąsiedztwa, opublikowano wspomnienie Jana Kazimierza Szeptyckiego pt.: Gdy w rodzinie ważyty się losy

2 Mniejszą wagę mają wydane przez syna komediopisarza fragmenty jego wspomnień: J. A. Fredro, Dwa rozdziały ze wspomnień Jana Aleksandra hr. Fredry, Kraków 1898.

3 M. z Fredrów Szembekowa, Niegdyś... wspomnienia moje o Aleksandrze Fredrze, z przedmową A. Grzymały-Siedleckiego, Lwów-Warszawa-Kraków 1927.

4 A. Fredro, Pisma wszystkie. Wydanie krytyczne, opracował S. Pigoń, t. XIV, Korespondencja, wybór i opracowanie tekstów K. Czajkowska i S. Pigoń, Warszawa 1976.

5 Z. z Fredrów Szeptycka, Wspomnienia z lat ubiegłych, przyg., wstęp i przypisy B. Zakrzewski, Wrocław-Warszawa-Kraków 1967.

6 Fredro ifredrusie, opr. B. Zakrzewski, Wrocław-Warszawa-Kraków-Gdańsk 1974.

7 Z. z Fredrów Szeptycka, Młodość i powotanie ojca Romana Andrzeja Szeptyckiego zakonu św. Bazylego Wielkiego powiedziane przez Matkę jego 1865-1892, opracował B. Zakrzewski, Wrocław 1993.

8 S. Stępień, Nieznany list Metropolity Andrzeja Szeptyckiego do Administratora Apostolskiego Łemkowszczyzny Wasyla Maściucha, „Przemyskie Zapiski Historyczne” 1985, z. 3, s. 201-210. 
syna... Rzecz o Romanie Marii Aleksandrze Szeptyckim późniejszym greckokatolickim metropolicie Andrzeju w świetle dokumentów rodzinnych ${ }^{9}$.

Jeszcze pod koniec lat 80. w miesięczniku „Znak” (1988) opublikowano trzy listy pasterskie metropolity z czasów II wojny światowej, poprzedzone zarysem jego sylwetki sporządzonym przez pioniera problematyki ukraińskiej w Polsce Ryszarda Torzeckiego $^{10}$. W kilka lat później historyk ten wydał i opatrzył komentarzem tłumaczenie listu pasterskiego biskupów greckokatolickich z 1943 r. ${ }^{11}$. Szczególne zasługi na polu publikacji źródłowych położyli w tym czasie historyk Andrzej A. Zięba i historyk kościoła ks. Józef Wołczański. Pierwszy z nich wydał, opracował i opatrzył wstępem Wspomnienie o Metropolicie Andrzeju Romanie Szeptyckim ... spisane przez Zofię Szembekównę, w zakonie siostrę Marię Krystę ${ }^{12}$. W kilka lat później ukazał się pod jego redakcją tom zatytułowany: Metropolita Andrzej Szeptycki. Studia i materiały (Kraków 1994), w którym zamieszczono m.in. cenne materiały wspomnieniowe i fragmenty korespondencji pióra Jana Kazimierza Szeptyckiego, Elżbiety z Szeptyckich Weymanowej, Anny Szeptyckiej i Tadeusza Fedorowicza ${ }^{13}$. Natomiast ks. Wołczański wydał, opracował i opatrzył wstępem materiały źródłowe, które miały szczególne znaczenie dla zrozumienia stosunku Szeptyckiego do Polski i Polaków. Ukazały się one jako Korespondencja arcybiskupa Bolestawa Twardowskiego z arcybiskupem Andrzejem Szeptyckim w latach 1943-1944 ${ }^{14}$, Arcybiskup Andrzej Szeptycki wobec polskiej racji stanu $w$ latach 1921-192215 oraz osobny tom pt.: Nieznana korespondencja arcybiskupów metropolitów lwowskich Józefa Bilczewskiego z Andrzejem Szeptyckim w czasie wojny polsko-ukraińskiej 1918-1919 (1997) ${ }^{16}$. Na uwagę zasługują także publikacje źródłowe pod redakcją osób z kręgu rodziny Szeptyckich. Metropolita Andrzej Szeptycki. Pisma

9 J. K. Szeptycki, Gdy w rodzinie ważyly się losy syna, [w: ] Polska-Ukraina 1000 lat sąsiedztwa, t. 1, Studia z dziejów chrześcijaństwa na pograniczu etnicznym, red. S. Stępień, Przemyśl 1990, s. 181-198.

10 R. Torzecki, Metropolita Andrzej Szeptycki, „Znak” 1988, nr 9 (400), s. 55-63; Listy metropolity lwowskiego Andrzeja Szeptyckiego, „Znak” 1988, nr 9 (400), s. 64-78.

11 R. Torzecki, Nieznany list Metropolity Szeptyckiego, „Więż” 1998, nr 3 (473), s. 134-142.

12 Siostra Maria Krysta, Wspomnienia o Metropolicie Andrzeju Romanie Szeptyckim spisane dla dzieci i wnuków mej ukochanej siostry Jadwigi Szeptyckiej [opr. A. A. Zięba], „Harward Ukrainian Studies” June 1991, vol. 15, nr 1-2, s. 108-171.

13 J. K. Szeptycki, W kręgu rodziny Szeptyckich, [w:] Metropolita Andrzej Szeptycki. Studia i materiaty, red. A. A. Zięba, Kraków 1994, s. 17-23; E. z Szeptyckich Weymanowa, Leon i Jadwiga Szeptyccy wobec osoby i dzieta metropolity Andrzeja Szeptyckiego, [w] tamże, s. 25-33; A. Szeptycka, Fragmenty listu do o. Jacka Woronieckiego OP, [w] tamże, s. 35-37; T. Fedorowicz, Moje wspomnienie o Ś. P. księdzu Metropolicie Andrzeju Szeptyckim, [w:] tamże, s. 39-40.

14 J. Wołczański, Korespondencja arcybiskupa Bolesława Twardowskiego z arcybiskupem Andrzejem Szeptyckim w latach 1943-1944, „Przegląd Wschodni” 1992/3, z. 2 (6), s. 465-484.

15 J. Wołczański, Arcybiskup Andrzej Szeptycki wobec polskiej racji stanu w latach 1921-1922, [w:] Stromata historica in honorem Romani Mariae Zawadzki, Kraków 2006, s. 601-651.

16 Nieznana korespondencja arcybiskupów metropolitów lwowskich Józefa Bilczewskiego z Andrzejem Szeptyckim w czasie wojny polski-ukraińskiej 1918-1919, opr., wstęp, przypisy, indeksy, wybór aneksów i fotografii J. Wołczański, Lwów- Kraków 1997. 
wybrane (2000) ${ }^{17}$ przygotowane do druku przez Marię H. Szeptycką i o. Marka Skórkę OSBM stanowily próbę udostępnienia polskiemu odbiorcy chociaż części bogatej spuścizny po metropolicie. W XXI w. szczególnie zaznaczył się wkład politologa Andrzeja Szeptyckiego. W 2011 w wydanym pod jego redakcją tomie pt. Kościót, naród, państwo. Działalność i dziedzictwo Metropolity Andrzeja Szeptyckiego (1865-1944) ${ }^{18}$ ukazało się Świadectwo Kurta Lewina na temat znaczenia postawy metropolity i jego brata Kazimierza (Klemensa) Szeptyckiego wobec antysemityzmu i systemów totalitarnych. Obecnie A. Szeptycki przygotowuje do druku tom studiów pt. Arystokrata ducha. Życie i dziedzictwo błogostawionego ojca Klemensa Szeptyckiego (1869-1951), w którym znajdą się również materiały o charakterze quasi-wspomnieniowym.

Wydawnictwa źródłowe, stanowily jedynie preludium do podejmowania przez polskich badaczy prób analizy i naświetlenia różnych zagadnień związanych z postacią Andrzeja Szeptyckiego. Redaktorzy poszczególnych wydań źródłowych dokonywali pierwszych prób interpretacji i umiejscowienia wydarzeń z życia metropolity w szerszym kontekście. Do prekursorów tych badań można zaliczyć przede wszystkim historyków Ryszarda Torzeckiego, Andrzeja A. Ziębę, oraz historyka literatury Bogdana Zakrzewskiego. Pierwszy z nich, w pionierskich, jak na tamte czasy, i fundamentalnych dla badań nad problematyką ukraińską oraz stosunkami polsko-ukraińskimi pracach: Kwestia ukraińska w polityce III Rzeszy (1933-1945) (1972) ${ }^{19}$, Kwestia ukraińska w Polsce w latach 1923-1929 (1989) ${ }^{20}$ oraz Polacy i Ukraińcy. Sprawa ukraińska w czasie II wojny światowej na terenie II Rzeczypospolitej (1993) ${ }^{21}$ przedstawił m.in. rolę Szeptyckiego w analizowanych wydarzeniach. Było to ujęcie adekwatnie do poruszanej problematyki, umieszczające postać metropolity w szerokim kontekście historycznym. Owocem jego badań nad rolą Szeptyckiego były też, równie pionierskie, artykuły Torzeckiego próbujące przybliżyć motywacje postępowania metropolity wobec wydarzeń pierwszej połowy XX w. ${ }^{22} \mathrm{~W}$ jednym z nich, opublikowanym w „Więzi” w 1988 r., historyk przedstawił zarys najważniejszych zagadnień związanych z metropolitą oraz próbę

17 Metropolita Andrzej Szeptycki. Pisma wybrane, wybór i przygotowanie do druku M. H. Szeptycka, M. Skórka, Kraków 2000.

18 Kościót, naród, państwo. Dziatalność i dziedzictwo Metropolity Andrzeja Szeptyckiego (1865-1944), materiały z międzynarodowej konferencji w Krakowie 25-26 listopada 2009 roku, red. A. R. Szeptycki, Wrocław-Warszawa 2011.

19 R. Torzecki, Kwestia ukrainska w polityce III Rzeszy (1933-1945), Warszawa 1972.

20 Tenże, Kwestia ukraińska w Polsce w latach 1923-1929, Kraków 1989.

21 Tenże, Polacy i Ukraińcy. Sprawa ukraińska w czasie II wojny światowej na terenie II Rzeczypospolitej, Warszawa 1993.

22 Tenże, Metropolita Andrzej Szeptycki, „Znak” 1988, nr 9 (400), s. 55-63; tenże, Postawa metropolity, „Więż” 1988, nr 7-8, s. 99-115; tenże, W obronie zasad, $w$ dobie próby... , „Dzieje Najnowsze” 1993, nr 1, s. 111-116; Myśl ekumeniczna metropolity Szeptyckiego a porozumienie Kościoła rzymskokatolickiego z Cerkwią prawosławną, „Dzieje Najnowsze" 1996, nr 1, s. 221-226. 
oceny jego postaci ${ }^{23}$. Natomiast w przełomowym dla światowych badań nad Szeptyckim kanadyjskim tomie pod red. Raula Roberta Magocsi'ego pt.: Morality and reality. The Life and Times of Andrei Sheptyts'kyi (1989) ukazał się tekst Torzeckiego ${ }^{24}$ o relacjach metropolity z polskim społeczeństwem.

Z kolei Ryszard Łużny i Andrzej A. Zięba w 1990 r. współorganizowali, pod patronatem Komisji Słowianoznawstwa PAN, międzynarodową konferencję pt.: Metropolita Andrzej Szeptycki a kultura duchowa narodów Europy Środkowo-Wschodniej. Jej pokłosiem stała się, wspomniana już wcześniej, publikacja Metropolita Andrzej Szeptycki. Studia i materiały (1994) mająca przełomowe znaczenie dla polskich badań nad postacią metropolity. A. Zięba był nie tylko jej redaktorem, ale także autorem ważnych artykułów. Pierwszy z nich został poświęcony genezie decyzji Romana Szeptyckiego o zmianie obrządku ${ }^{25}$, a drugi podsumowywał prowadzone badania nad postacią metropolity ${ }^{26}$. Krakowski historyk opracował też cenną dla kolejnych badaczy chronologię życia Szeptyckiego ${ }^{27}$. W tym samym tomie znalazły się również teksty innych znaczących polskich autorów, podejmujących próbę przybliżenia poszczególnych obszarów działalności metropolity: Stanisława Stępnia, Mirosławy Papierzyńskiej-Turek, Macieja Mroza, ks. Tadeusza Śliwy ${ }^{28}$. A. A. Zięba jest również autorem innych ważnych publikacji o metropolicie. We wspomnianym już kanadyjskim tomie Morality and reality... został opublikowany jego istotny tekst o postaci Szeptyckiego w polskiej opinii publicznej. W innych artykułach poruszał Zięba m.in. problem legendy pośmiertnej Szeptyckiego wśród Polaków ${ }^{29}$.

Zasługi Bogdana Zakrzewskiego w udostępnieniu, wspomnianego wcześniej, materiału źródłowego z kręgu rodzin Fredrów i Szeptyckich są trudne do przecenienia

23 Tenże, Postawa metropolity, „Więż” 1988, nr 7-8, s. 99-115.

24 Tenże, Sheptyts'kyi and Polish Society, [w: ] Morality and Reality. The Life and Times of Andrei Sheptyts'kyi, ed. P. R. Magocsi, Edmonton 1989, s. 75-98.

25 A. A. Zięba, W sprawie genezy decyzji Romana Szeptyckiego o zmianie obrządku, [w:] Metropolita Andrzej Szeptycki. Studia i materialy ..., s. 43-64.

26 Tenże, Krakowska konferencja na temat metropolity Szeptyckiego na tle dotychczasowego dorobku naukowego, [w: ] Metropolita Andrzej Szeptycki. Studia i materiaty..., s. 239-247.

27 Tenże, Chronologia życia metropolity Andrzeja Szeptyckiego, [w:] Metropolita Andrzej Szeptyckie. Studia i materiaty..., s. 253-258.

28 Teksty zawarte w tomie Metropolita Andrzej Szeptycki. Studia i materialy ...: S. Stępień, Stanowisko metropolity Andrzeja Szeptyckiego wobec zjawiska terroru politycznego (s. 109-121); M. Papierzyńska-Turek, Metropolita Andrzej Szeptycki wobec prawosławia 1918-1939 (s. 181-189); M. Mróz, Unijne plany metropolity Szeptyckiego w Rosji i Polsce w latach 1917-1922 (s. 169-180), T. Śliwa, Kontakty metropolity Szeptyckiego ze Stolica Apostolska w okresie II wojny światowej w świetle „Actes et documents du Saint Siége relatifs á la seconde guerre mondiale” (s. 191-205).

29 Tenże, Dzieje legendy pośmiertnej metropolity Andrzeja Szeptyckiego wśród Polaków, [w:] Polska-Ukraina 1000 lat sąsiedztwa, T. 4, Katolickie unie kościelne w Europie Środkowej i Wschodniej - idea a rzeczywistość, red. S. Stępień, Przemýl 1998, s. 287-310. O wydarzeniach naukowych i kulturalnych związanych z metropolitą w okresie transformacji ustrojowej w Polsce i na Ukrainie pisał Zięba w tekście: tenże, O metropolicie Szeptyckim w Krakowie i Lwowie, „Znak” 1990, nr 10-11 (425-426), s. 182-185. 
przecenić. Na przełomie lat 80 . i 90 . XX wieku opublikował on także kilka artykułów m.in. o pobycie Szeptyckiego w Zakopanem ${ }^{30}$ oraz na studiach we Wrocławiu ${ }^{31}$.

W 1985 r. ukazała się praca Edwarda Prusa pt.: Wtadyka świętojurski. Rzecz o arcybiskupie Andrzeju Szeptyckim (1865-1944) 32, która spotkała się z ostrą krytyką polskiego środowiska naukowego, wyrażoną w recenzjach historyków R. Torzeckiego, A. A. Zięby i Władysława Serczyka ${ }^{33}$. Autorowi zarzucano m.in. blędy metodologiczne, nieadekwatność sądów i wniosków oraz nieścisłości źródłowe. Jej „rozszerzona, poprawiona i uzupełniona wersja” - jak zaznaczył we wstępie autor - ukazała się w 1999 r. pt. Patriarcha galicyjski $i^{34}$. Stanowi ona, jak dotąd, jedyną próbę całościowego przedstawienia postaci metropolity w ujęciu biograficznym w Polsce.

W latach 90. polskie środowisko naukowe chętnie podejmowało wspólpracę ze środowiskiem ukraińskim. Wyrazem tego były wspomniane wyżej konferencje. Na szczególną uwagę zasługuje ta zorganizowana w Gdańsku 5 listopada 1994 r., w rocznicę pochowania metropolity w katedrze św. Jura. Była ona owocem współpracy prof. Włodzimierza Mokrego z Uniwersytetu Jagiellońskiego z prof. Tadeuszem Stegnerem z Uniwersytetu Gdańskiego, Koła Naukowego Historyków UG, Związku Ukraińców w Polsce oraz redakcji czasopisma „Peremyskie Dzwony”. Jej owocem jest tom pt.: Metropolita Andrzej Szeptycki, pod red. T. Stegnera, w którym znalazły się teksty pióra Włodzimierza Mokrego, Eugeniusza Koko, Czesława Partacza, Zbigniewa Opackiego, Magdaleny Nowak oraz teologa Jarosława Moskałyka ${ }^{35}$. Tom stanowil chronologiczne drugą na gruncie polskim próbę jak najpełniejszego ukazania postaci Szeptyckiego.

Od przełomu lat 80. i 90 liczba polskich publikacji poświęconych różnym aspektom życia i działalności metropolity uległa znacznemu zwiększeniu. Niewątpliwy wpływ na to miało uwolnienie badań naukowych po przemianach 1989/1990 r. oraz znaczny wzrost możliwości penetrowania archiwów i bibliotek w kraju i za granicą. Obserwowana zmiana jest nie tylko ilościowa, jak i jakościowa.

30 B. Zakrzewski, Brat Andrzej Szeptycki w Zakopanem, „Wierchy”, 1987 [1992], s. 213-216.

31 Tenże, Studia wrocławskie metropolity Szeptyckiego, „Acta Universitatis Wratislaviensis. Prace literackie”, t. 33 (1601), 1994, s. 87-100.

32 E. Prus, Wtadyka świętojurski. Rzecz o arcybiskupie Andrzeju Szeptyckim (1865-1944), Warszawa 1985.

33 A. A. Zięba, Metropolita Andrzej Szeptycki, „Kwartalnik Historyczny”, 1985, z. 4, s. 885-900; W. A. Serczyk, R. Torzecki, Na marginesie książki Edwarda Prusa o Metropolicie Szeptyckim, „Dzieje Najnowsze”, 1986, t. 18, z. 1, s. 103-119.

34 E. Prus, Patriarcha galicyjski. Rzecz o arcybiskupie Andrzeju Szeptyckim metropolicie greckokatolickim (1865-1944), Wrocław 1999.

35 Zawartość tomu Metropolita Andrzej Szeptycki, materiały z sesji naukowej, red. T. Stegner, Ostaszewo Gdańskie 1995: W. Mokry, Idea patriarchatu w dziele metropolity Andrzeja Szeptyckiego (s. 7-22); J. Moskałyk, Metropolita Andrzej Szeptycki od powszechności do jedności Kościotów (s. 23-31); Cz. Partacz, Metropolita Andrzej Szeptycki wobec skrajnych postaw religijno-politycznych spoteczeństwa Galicji Wschodniej (s. 32-54); E. Koko, Metropolita Andrzej Szeptycki a państwo polskie w latach 1918-1939, (s. 55-69); M. Nowak, Między Hitlerem a Stalinem. Metropolita Andrzej Szeptycki wobec systemów totalitarnych w latach 1939-1944 (s. 70-88); Z. Opacki, Marian Zdziechowski - adresat listów arcybiskupa metropolity Andrzeja Szeptyckiego (s. 89-118). 
Pośród tych wydawnictw znajdujemy monografie, artykuły oraz biogramy. Do najważniejszych z pewnością należą biogramy zawarte w t. 48/2 „Polskiego Stownika Biograficznego" ${ }^{\prime 36}$, które obejmują samego metropolitę, jak i członków jego rodziny. Ich autorami byli m.in. Stanisław Tadeusz Sroka (Jadwiga z Szembeków Szeptycka), Anna Siudak (Zofia Szeptycka), Andrzej Przegaliński (Aleksander Szeptycki), Piotr Mikietyński (Stanisław Szeptycki), S. Stępień (Kazimierz Szeptycki, Józef Gabiel Szeptycki, Jan Kanty Szeptycki - współautorstwo z M. Nowak), M. Nowak (Andrzej Szeptycki, Zofia z Fredrów Szeptycka, Jan Kanty Szeptycki - współautorstwo z S. Stępniem). Istnieją też dość liczne biogramy poświęcone metropolicie zamieszczone w kościelnych publikacjach słownikowych oraz pracach poświęconych historii Kościoła ${ }^{37}$.

Poza tymi próbami całościowego ujęcia biografii Szeptyckiego pojawiło się wiele publikacji omawiających jedynie jeden $\mathrm{z}$ aspektów działalności lub wybrany fragment życiorysu metropolity. Na przełomie XX i XXI w. ukazały się monografie Dariusza Kalińskiego ${ }^{38}$ Teologiczne tradycje nauki o Najświętszej Maryi Pannie w Kościele greckokatolickim na przykładzie pism arcybiskupa Andrzeja Szeptyckiego oraz ks. Adama Kubasika Arcybiskupa Andrzeja Szeptyckiego wizja ukraińskiego narodu, państwa i cerkwi (1999) ${ }^{39}$. W $2011 \mathrm{r}$. z inicjatywy Fundacji Rodu Szeptyckich we współpracy z Kolegium Europy Wschodniej im. Jana Nowaka- Jeziorańskiego, ukazała się, wspominana już, praca zbiorowa pod red. A. Szeptyckiego pt. Kościót, naród, państwo. Działalność i dziedzictwo metropolity Andrzeja Szeptyckiego (1865-1944). Zawarto w niej teksty takich autorów, jak Włodzimierz Mokry, Piotr Siwicki i Grzegorz Motyka ${ }^{40}$. Na uwagę zasługują też prace poświęcone osobom z otoczenia metropolity. Zawarte w nich wyniki badań mogą pomóc w dalszych studiach nad postacią arcybiskupa Andrzeja. Dotyczyły one Stanisława Szeptyckiego (A. Wojtaszak ${ }^{41}$, P. Mikietyński ${ }^{42}$ ) oraz Aleksandra Fredry (B. Lasocka ${ }^{43}$ ). Natomiast w przygotowaniu znajduje się, wspomniany wcześniej, tom pod red. A. Szeptyckiego pt. Arystokrata ducha. Życie i dziedzictwo błogosławionego ojca Klemensa Szeptyckiego (1869-1951), zawierający

36 „Polski Stownik Biograficzny”, t. 48/2, z. 197, Warszawa-Kraków 2012.

37 A. Andrusiewicz, Szeptycki Andrzej, [w: ] Stownik biograficzny katolicyzmu spotecznego w Polsce, R-Ż, Lublin 1995, s. 101-104; H. E. Wyczawski, Cerkiew greckokatolicka, [w:] Historia Kościoła w Polsce, t. II 1764-1945, cz. 2 1918-1945, red. B. Kumor, Z. Obertyński, Poznań-Warszawa 1979, s. 77-84; T. Śliwa, Kościół greckokatolicki w Polsce w latach 1918-1939, [w:] Kościót w II Rzeczpospolitej, red. Z. Zieliński, S. Wilk, Lublin 1980, s. 149-165.

38 D. Kaliński, Teologiczne tradycje nauki o Najświętszej Maryi Pannie w Kościele greckokatolickim na przykładzie pism arcybiskupa Andrzeja Szeptyckiego, Niepokalanów 1996.

39 A. Kubasik A., Arcybiskupa Andrzeja Szeptyckiego wizja ukraińskiego narodu, państwa i cerkwi, Kraków 1999.

40 Zawartość tomu Kościót, naród, państwo. Działalność i dziedzictwo Metropolity Andrzeja Szeptyckiego... : W. Mokry, „Mądrość Boża” i „prawość chrześcijańska” w myśli filozoficzno-teologicznej metropolity Andrzeja Szeptyckiego (s. 29-38); P. Siwicki, Andrzej Szeptycki: „patriarcha galicyjski” czy metropolita całej Rusi (s. 39-50); G. Motyka, Metropolita Andrzej Szeptycki a konflikt polsko-ukraiński w czasie II wojny światowej (s. 275-298).

41 A. Wojtaszak, Generat broni Stanistaw Szeptycki (1867-1950), Szczecin 2000.

42 P. Mikietyński, Generat Stanistaw hr. Szeptycki: między Habsburgami a Rzeczpospolita (okres 1867-1918), Kraków 1999.

43 B. Lasocka. Aleksander Fredro. Drogi życia, Warszawa 2001. 
m.in. artykuły takich uczonych, jak J. Moskałyk, P. Siwicki, Ł. Adamski, S. Stępień, A. Szeptycki, R. Zubkowicz, G. Motyka, Ł. Jasina, M. Nowak.

Należy zauważyć, że większość publikacji polskich uczonych poświęconych Szeptyckiemu stanowią artykuly w czasopismach lub pracach zbiorowych, nierzadko publikowane również na Ukrainie i w języku ukraińskim. Spośród zagadnień w nich poruszanych, do najważniejszych można zaliczyć analizę problematyki politycznej i społecznej (Cz. Partacz ${ }^{44}$, E. Koko ${ }^{45}$, Z. Opacki ${ }^{46}$, Romuald Jankiewicz ${ }^{47}$, Marek Figu$\mathrm{ra}^{48}$ ) kulturalnej (Marek Mariusz Tytko ${ }^{49}$ ), myśli teologicznej, eklezjalnej i nauczania, (W. Mokry ${ }^{50}$,J. Moskałyk ${ }^{51}$, A. Kubasik ${ }^{52}$, S. Stępien ${ }^{53}$, M. Nowak ${ }^{54}$, M. M. Tytko ${ }^{55}$, Walter Żelazny $^{56}$, Antoni Kiełbasa ${ }^{57}$ ), historiozofii (M. Nowak ${ }^{58}$ ), problemu mitu i legendy

44 Cz. Partacz, Metropolita Andrzej Szeptycki wobec skrajnych postaw religijno-politycznych społeczeństwa Galicji Wschodniej, [w:] Metropolita Andrzej Szeptycki, materiały z sesji naukowej..., s. 32-54.

45 E. Koko, Metropolita Andrzej Szeptycki a państwo polskie w latach 1918-1939, [w:] tamże, s. 55-69.

46 Z. Opacki, Marian Zdziechowski-adresat listów arcybiskupa metropolity Andrzeja Szeptyckiego, [w:] tamże, s. 89-118.

47 M. Zimomrja, R. Jankiewicz, Etyczno-spoteczne aspekty nauczania pasterskiego metropolity Andrzeja Szeptyckiego, „Studia Koszalińsko-Kołobrzeskie” 2001, nr 6, s. 259-268.

48 M. Figura, Działalność metropolity A. Szeptyckiego w latach 1921-1923 w świetle prasy Polski zachodniej i pótnocnej, „Rocznik Wschodni” 2000, nr 6, s. 155-180.

49 M. M. Tytko, W kręgu Andrzeja Szeptyckiego. Kulturalne odrodzenie ukraińskie za czasów mecenatu metropolity, [w:] Dzieje Podkarpacia, t. 3, red. J. Gancarski, Krosno-Rzeszów 1999, s 31-50.

50 W. Mokry, Metropolita Andrzej Szeptycki w stużbie jedności chrześcijan Wschodu i Zachodu, [w:] Unia Brzeska. Przeszłość i teraźniejszość 1596-1996, materiały międzynarodowego sympozjum Kraków, 19-20 listopada 1996, Kraków 1998, s. 173-186.

51 Moskałyk J., Wizja Kościoła Andrzeja Szeptyckiego w kontekście nowych wyzwań międzykonfesyjnych na progu XXI wieku, [w:] Polska-Ukraina 1000 lat sąsiedztwa, t. 5, Miejsce i rola Kościoła greckokatolickiego w Kościele powszechnym, red. S. Stępień, Przemyśl 2000, s. 115-122.

52 Kubasik A., Problematyka kapłaństwa i rodziny w nauczaniu metropolity Andrzeja Szeptyckiego, [w:] Polska-Ukraina 1000 lat sąsiedztwa, t. 5, Miejsce i rola Kościoła greckokatolickiego w Kościele powszechnym, red. S. Stępień, Przemyśl 2000, s. 103-114; tenże, Ideat życia zakonnego wedtug ,metropolity Andrzeja Szeptyckiego, „Saeculum Christianum" 2002, nr 1, s. 127-142.

53 S. Stępień, W poszukiwaniu tożsamości obrządkowej. Bizantynizacja a okcydentalizacja Kościoła greckokatolickiego w okresie międzywojennym, [w: ] Polska - Ukraina. 1000 lat sąsiedztwa, t. 5 ..., s. 87-102; ukraiński wariant tego art.: С. Стемпень, Між окциденталізацією та візантинізачією: проблема обрядової ідентичності Греко-Католицької Церкви в Речі Посполитій міжвоєнного періоду, „Ковчег. Науковий збірник із церковної історіі” 2003, t. 4, s. 86-100.

54 M. Nowak M., Gtówne kategorie społeczne w listach pasterskich metropolity Andrzeja Szeptyckiego, „Eüdoc”. Альманах теорії та історії історичної науки, вип. 5, Київ 2010/2011, s. 457-483.

55 M. M. Tytko, Studyci. Odrodzenie zakonu przez metropolitę Andrzeja Szeptyckiego, [w:] Dzieje Podkarpacia, t. $3 \ldots$, s. 51-67.

56 W.Żelazny, Brzeska unia kościelna oraz postać metropolity Szeptyckiego przedstawiona na konferencjach naukowych Uniwersytetu Katolickiego w Lyonie, „Biuletyn Ukrainoznawczy” 2000, nr 6, s. 268-278; tenże, „Konwersje” Metropolity Andrzeja Szeptyckiego jako problem Kościoła katolickiego w Polsce, „Przegląd Religioznawczy” 2001, nr 1, s. 3-21.

57 A. Kiełbasa, Metropolita Andrzej Roman Maria Szeptycki wobec myśli unijnej, [w: ] Z dziejów wrocławskiego Kościoła katolickiego. Tendencje unijne, red. I. Dec, K. Matwijowski, Wrocław 2002, s. 61-68.

58 M. Nowak, Rola Kościoła greckokatolickiego w wizji dziejów Rusi-Ukrainy metropolity Andrzeja Szeptyckiego, [w:] Dziedzictwo Świętego Włodzimierza, zbiór studiów, red. T. Stegnera, Gdańsk 2016, s. 107-127; tejże, Między Wschodem i Zachodem. Kościót greckokatolicki w refleksji historiozoficznej metropolity Andrzeja Szeptyckiego, [w:] Historia-Mentalność-Tożsamość. Rosja i Europa Zachodnia w polskiej i ukraińskiej historiografii XIX $i$ XX wieku, red. E. Koko, M. Nowak, L. Zaszkilniak, Gdańsk 2013, s. 331-348. 
(A. A. Zięba ${ }^{59}$, M. Nowak ${ }^{60}$ ), miejsca we współczesnej kulturze ukraińskiej (Łukasz Jasina $^{61}$ ), stosunku do Polaków (S. Stępień ${ }^{62}$, Hanna Dylągowa ${ }^{63}$ ), świadomości historycznej (M. Nowak ${ }^{64}$ ), stosunku do zbrodni II wojny światowej - Holokaustu, reżimu sowieckiego oraz rzezi wołyńskiej (G. Motyka ${ }^{65}$, S. Stępieñ $^{66}$, P. Siwicki ${ }^{67}$, M. Nowak ${ }^{68}$ ), powiązań rodzinnych oraz okresu dzieciństwa i młodości (M. Nowak ${ }^{69}$ ) oraz identyfikacji narodowej (S. Stępien ${ }^{70}$, M. Nowak ${ }^{71}$ ), związków z poszczególnymi miejscami (B. Zakrzewski ${ }^{72}$, Artur Kijas i Maciej Zygmański ${ }^{73}$ ).

Podsumowując, należy dostrzec dużą wagę prac środowiska naukowego w Polsce dla badań nad postacią metropolity Szeptyckiego. W latach 80. i 90 torowały one drogę

59 A. A. Zięba, Dzieje legendy pośmiertnej metropolity Andrzeja Szeptyckiego wśród Polaków, [w:] Polska-Ukraina 1000 lat sasiedztwa, T. 4..., s. 287-310.

60 M. Nowak, Metropolita Andrzej Szeptycki - między rzeczywistością historyczną a mitologiczną, [w:] Mity i stereotypy w dziejach Polski i Ukrainy w XIX i XX wieku, red. A. Czyżewski, R. Stobiecki, T. Toborek, L. Zaszkilniak, Warszawa-Łódź 2012, s. 302-319.

61 Ł. Jasina, „Władyka Andrej” Otesia Jańczuka (2008) jako przykład wspótczesnego ukraińskiego kina historycznego, [w:] Kościót, naród, państwo ..., s.253-258.

62 С. Стемпень, Ставленння Митрополита Андрея Шептицького до Полщі та поляків, [w:] Мойсей українського духа, реА. $\Lambda$. Гентош, $\Lambda$ ьвів 2015, s. 246-251.

63 H. Dylągowa, Metropolita Andrzej Roman Szeptycki i Polacy, „Warszawskie Zeszyty Ukrainoznawcze” 2006, t. 21-22, red. S. Kozak, przy współpracy W. Sobola, B. Nazaruka, s. 62-66.

64 M. Nowak, Metropolita Andrzej Szeptycki w świadomości historycznej Polaków i Ukraińców,[w:] Historia. Mentalność. Tożsamość. Miejsce i rola historii oraz historyków w życiu narodu polskiego i ukraińskiego w XIX i XX w., red. J. Pisulińska, P. Sierżęga, L. Zaszkilniak, Rzeszów 2008, s. 528-540.

65 G. Motyka, Metropolita Andrzej Szeptycki a konflikt polsko-ukraiński w czasie II wojny światowej, [w:] Kościót, naród, państwo ..., s. 275-298.

66 С. Стемпень, Критика терору як методу вирішення національних і політичних конфліктів у пастирській науці митрополита Андрея Шептицького, „Наукові Записки Українського Католицького Університету”, ч. 2, серія Історія, в. 1, Аьвів 2010, s. 191-208.

67 P. Siwicki, Metropolita Andrzej Szeptycki a reżim hitlerowski w świetle wspomnień Józefa Lebedowicza, [w: Kościót, społeczeństwo, kultura, prace ofiarowane profesorowi Wiesławowi Müllerowi z okazji pięćdziesięciolecia pracy naukowej i dydaktycznej, red. J. Droba et al., Lublin 2004, s. 241-249.

68 M. Nowak, Między Hitlerem a Stalinem. Metropolita Andrzej Szeptycki wobec systemów totalitarnych w latach 1939-1944, [w: ] Metropolita Andrzej Szeptycki, materiały z sesji naukowej, ... s. 70-88.

69 M. Nowak, Lata szkolne Romana Aleksandra Szeptyckiego w Gimnazjum św. Anny w Krakowie (18791883), [w:] Polska i sąsiedzi. Studia z dziejów kultury, gospodarki i myśli politycznej. Księga pamiątkowa ofiarowana prof. Marianowi Mroczce w 70. rocznicę urodzin, red. M. Hejger, W. Skóra, Pruszcz Gdański - Słupsk 2010, s. 403-417; tejże, Środowisko młodości metropolity Andrzeja Szeptyckiego 1865-1892, [w:] Galicyjskie Spotkania 2010, tom studiów pod red prof. dr hab. U. Jakubowskiej, Kalisz BDW (2012), s. 60-81.

70 С. Стемпень, Поляк з походження та виховання, український архиєрей і патріот з вибору...Митрополит

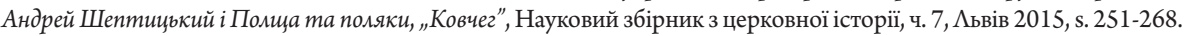

71 M. Nowak, Świadomość narodowa metropolity Andrzeja Szeptyckiego - moment wyboru - 1885 r. [w: ] Pogranicza. Ludzie pogranicza, red. W. Brenda, J. Kiełbik J., Olsztyn 2009, s.124-134; tejże, Działalność Romana Aleksandra Szeptyckiego w polskich organizacjach studenckich (Wroctaw 1884-1885, Kraków 1886-1887), [w:] Iсторя-ментальністьідентичність. Шсторична памєять українців і поляків у періоду формування начіональної свідомості в ХІХ - периій

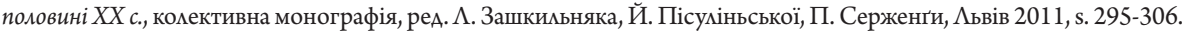

72 B. Zakrzewski, Brat Andrzej Szeptycki w Zakopanem, „Wierchy”, 1987 [1992], s. 213-216; tenże, Studia wroctawskie metropolity Szeptyckiego, „Acta Universitatis Wratislaviensis. Prace literackie” 1994, t. 33 (1601), s. 87-100.

73 A. Kijas, M. Zygmański, Metropolita Andrzej Szeptycki w Poznaniu, „Przegląd Wielkopolski” 1994, nr 1/2, s. 34-39. 
dla dalszych, pogłębionych studiów podjętych już w XXI wieku. W tym kontekście należy podkreślić rozległość zainteresowań badawczych naukowców w Polsce, przy jednoczesnym wyraźnym skupieniu części badaczy na relacji metropolity i różnych zjawisk z historii Polski. Na uwagę zasługuje także pojawienie się w ostatnich latach nowych kierunków badań, obejmujących m.in. zagadnienia tożsamościowe czy środowiskowe.

Spoglądając na dotychczasowy dorobek nauki polskiej na omawianym polu, można sformułować kilka postulatów badawczych. W pierwszym rzędzie należałoby dążyć do jak najbardziej całościowego ujęcia postaci Szeptyckiego, gdyż w dotychczasowych studiach uderza pewna przyczynkowość, wynikająca w dużej mierze z bardzo szerokiego obszaru badawczego. Uzyskanie takiego szerokiego spojrzenia na metropolitę wymagać będzie, jak się wydaje, dalszych, pogłębionych badań podstawowych oraz ponownego sięgnięcia do już spenetrowanych źródeł w celu ich reinterpretacji w duchu najnowszych osiągnięć nauki. Całościowe ujęcie postaci nie wydaje się być możliwe bez dalszego zacieśniania współpracy z naukowcami ukraińskimi, i bez uwzględniania w możliwie jak najszerszym zakresie osiągnięć nauki ukraińskiej w publikacjach polskich i vice versa. $Z$ tego względu warto podkreślić potrzebę przezwyciężenia trudności w przeplywie informacji i publikacji między Polską i Ukrainą oraz między polskim i ukraińskim środowiskiem naukowym. Pojawienie się w ostatnich latach licznych ukraińskich publikacji na omawiany temat, o różnym charakterze, $w$ tym kilku cennych monografii (Liliana Hentosz ${ }^{74}$, Augustyn Babiak ${ }^{75}$ ), powinno skłonić uczonych do stawiania nowych oryginalnych pytań i poszukiwania dotąd niewykorzystywanych źródeł. Należy podkreślić potrzebę międzynarodowej współpracy i wymiany myśli w kontekście badań nad Szeptyckim. Ranga jego postaci zasługuje bowiem na komplementarne ujęcie, które wykracza poza ramy wąsko rozumianej nauki narodowej.

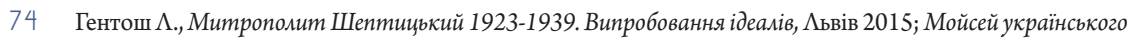

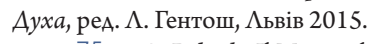

75 A. Babiak, Il Metropolita Andrea Szeptyckyj Nel suo incarico di visitatore apostolich (1920-1923) e nei suoi rapporti con il gaverno polacco, Trento-Bolzano 2012; ukraińskie wydanie tej pracy: А. Баб'як, Подвиг Митрополита Андрея Шептицького як апостольського візитатора для Украӥнців (1920-1923) і його взаємини з урядом Польщі, Тренто - Больцано 2013. 